\title{
OPTIMASI TARGET PRODUKSI BERBIAYA ALOKASI PEKERJAAN MINIMUM DENGAN PENDEKATAN PROGRAM LINIER (STUDI KASUS : PT. TASS ENGINEERING)
}

\author{
Helena Sitorus, Ratna Suminar, dan Arohman Dwi Santoso \\ Program Studi Teknik Industri, Fakultas Teknik, Universitas Bhayangkara Jakarta Raya \\ E-mail: helena.sitorus@dsn.ubharajaya.ac.id; gerora.sil@gmail.com; \\ railfans118@gmail.com
}

\begin{abstract}
Abstrak
PT. TASS Engineering adalah perusahaan yang bergerak di bidang karoseri truk. Perusahaan ini bekerja sama dengan pihak kedua (pemborong) dalam menyelesaikan pekerjaan untuk memenuhi pesanan pelanggan. Diantara produknya, terdapat 4 jenis produk (Dump Truck, Subframe, Tilting, dan Tanki Truck) yang pengerjaannya diserahkan kepada 4 tim pemborong. Keputusan alokasi pekerjaan dilakukan dengan cara memberikan pekerjaan kepada tim yang sudah menyelesaikan pekerjaan tertentu. Cara alokasi ini ternyata menimbulkan biaya tiap tim dalam mengerjakan satu jenis produk yang sama cukup bervariasi. Variasi biaya pengerjaan tentu saja berdampak bagi variasi keuntungan. Perlu ditentukan alokasi jenis dan jumlah pekerjaan yang tepat bagi masing-masing tim sehingga mendapatkan keuntungan yang maksimum. Hasil alokasi optimum adalah parameter keputusan kombinasi jumlah produksi tiap produk selain kapasitas tiap tim dan waktu pengerjaan.. Kombinasi jumlah tiap produk ini merupakan target produksi atau target penjualannya. Untuk itu diperlukan penelitian yang bertujuan 1) menentukan alokasi pekerjaan yang optimum, 2) menentukan target produksi tiap produk untuk mendapatkan keuntungan maksimum. Alokasi pekerjaan dilakukan dengan membandingkan metode Penugasan Hungarian dan metode Transportasi untuk memilih total biaya yang paling minimum. Solusi optimum jumlah produk yang diproduksi untuk mencapai keuntungan maksimum dilakukan dengan Program Linier. Hasi temuan penelitian menunjukkan bahwa 1) dump truck dikerjakan sebanyak $88 \%$ oleh tim-1 dan 12\% oleh tim-4; subframe dikerjakan sebanyak 39\% oleh tim-2, 26\% oleh tim-3, 35\% oleh tim-4; tilting dikerjakan oleh tim-3, dan tanki truk dikerjakan oleh tim-2. Target produksi (target penjualan) untuk mendapatkan keuntungan maksimum adalah dengan memproduksi dump truck 73 unit, subframe 120 unit, tilting 29 unit, dan tanki truk 33 unit. Solusi ini memberikan kenaikan keuntungan sebesar $0.9 \%$..
\end{abstract}

Kata kunci: optimum, Hungarian, Transportasi, Program Linier

\begin{abstract}
PT. TASS Engineering is a company engaged in the truck body. The company is working with a second party (contractor) in completing jobs to fulfill customer orders. Among its products, there are 4 types of products (Dump Truck, Subframe, Tilting, and Tanki Truck) whose job is submitted to 4 teams of contractors. The decision on job allocation is done by givingit to the team that have alredy completed their jobs. This allocation method turns out to cost each team to work on the same type of product that is quite varied. Variations in the cost of work, of course, have an impact on variations in profits. It is necessary to determine the allocation of the type and amount of work that is right for each team so as to get the maximum profit. The optimum allocation result is the decision parameter for the combination of the amount of production of each product in addition to the capacity of each team and the processing time. For this reason research is needed which aims to 1) determine the optimum allocation of work, 2) determine the production target of each product to get the maximum profit. The work allocation is done by comparing the Hungarian Assignment method and the Transportation method to choose the minimum total cost. The optimum solution for the number of products produced to achieve maximum profit is done by the Linear Program. The results of the research findings show that 1) dump trucks were handled by $88 \%$ by team- 1 and $12 \%$ by team- 4 ; subframes are done by $39 \%$ by team- $2,26 \%$ by team-3, $35 \%$ by team- 4 ; tilting is done by team-3, and truck tank is done by team-2; 2)the production target (sales target) to get maximum profit is to produce 73 units of dump trucks, 120 units of subframes, 29 units of tilting, and 33 units of tank trucks. This solution provides a profit increase of $0.9 \%$.
\end{abstract}

\section{Keywords: optimum, Hungarian, Transportation, Linier Programming}

\section{PENDAHULUAN}

Target produksi bagi perusahaan adalah keputusan penting untuk mendapatkan keuntungan yang maksimum. Target produksi bagi perusahaan yang kegiatan produksinya dilakukan oleh 
beberapa pihak (rekanan) sangat terkait dengan keputusan optimum alokasi pekerjaan. Keputusan untuk megalokasikan sejumlah pekerjaan tertentu pada tiap-tiap pihak bertujuan untuk meminimisasi biaya produksi. Hasil optimum alokasi pekerjaan tersebut adalah parameter untuk menentukan solusi optimum jumlah produksi masing-masing pekerjaan. Parameter lain yang menjadi pertimbangan adalah jumlah kapasitas produksi dan jumlah permintaa. Keseluruhan parameter-parameter tersebut secara bersamaan merupakan hal yang harus dipenuhi dalam menentukan solusi optimum jumlah masing-masing pekerjaan. Solusi optimum ditentukan dengan mengacu pada tujuan keuntungan yang maksimum. Solusi optimum inilah yang merupakan target produksi perusahaan.

Alokasi pekerjaan dapat dilakukan dengan metode Assignment (Penugasan) Hungarian atau metode Transportasi. Masalah Penugasan (assignment problem) adalah suatu masalah mengenai peraturan objek untuk melaksanakan tugas, dengan tujuan meminimalkan biaya, waktu, jarak, dan sebagainya ataupun untuk memaksimalkan keuntungan. Metode Paendong dan Prang (2011), mengungkapkan Metode Hungarian adalah metode yang memodifikasi baris dan kolom dalam matriks efektifitas sampai muncul sebuah komponen non tunggal dalam setiap baris atau kolom yang dapat dipilih sebagai alokasi penugasan. Semua alokasi penugasan yang dibuat adalah alokasi yang optimal, dan saat diterapkan pada matriks efektifitas awal akan memberikan hasil penugasan yang paling minimum. Metode Transportasi adalah suatu metode yang digunakan untuk mengatur distrbusi suatu produk (barang-barang) dari sumber-sumber yang menyediakan produk ke tempat-tempat tujuan secara optimal. Tujuan dari model ini adalah menentukan jumlah yang harus dikirim dari setiap sumber ke setiap tujuan sedemikian rupa dengan total biaya transportasi minimum (Walangitan, 2013).

Metode Transportasi diawali dengan solusi layak dasar dan kemudian dicari solusi optimumnya. Solusi layak dasar dapat dilakukan dengan 3 pendekatan yaitu North West Corner Method atau yang lebih dikenal Metode Sudut Barat Laut, Metode Biaya Terendah (Least Cost), dan Metode Vogel Approximation (VAM). Solusi optimum dapat dilakukan dengan Metode Stepping-Stone. Metode Barat Laut mengisi tabel awal transportasi dari sisi barat laut (kiri atas) dengan kuantitas sebanyak banyaknya. Metode Biaya Terendah (Least Cost) menyusun tabel matriks awal transportasi dengan cara pengalokasian distribusi barang dari sumber ke tujuan dimulai dari sel yang memiliki biaya distribusi terkecil. Metode Vogel Approximation (VAM) menyususn tabel matriks awal pada biaya terendah di baris atau kolom yang pinaltinya tertinggi. Metode Stepping-Stone adalah metode yang merubah alokasi produk untuk mendapatkan alokasi produk yang optimal menggunakan cara trial \& eror. Trial \& eror adalah mencoba memindahkan sel yang ada isinya (Stone) ke sel yang kosong.

Solusi optimum untuk mendapatkan keuntungan diperoleh dengan Program Linier. Apabila keputusan yang diambil harus bilangan bulat, maka digunakan Program Linier Bilangan Bulat (Integer Linier Programming) dimana salah satu pendekatannya adalah Branch and Bound. Alat untuk melakukan perhitungan dilakukan dengan Metode Simpleks. Metode Simpleks merupakan bagian dari linear programming yang digunakan sebagai alat untuk memecahkan permasalahan yang menyangkut dua variabel keputusan atau lebih. Metode ini menggunakan pendekatan tabel yang dinamakan tabel simpleks. Proses eksekusi untuk mendapatkan hasil optimum dengan mengubah-ubah tabel simpleks sampai diperoleh hasil positif di seluruh elemen nilai di baris $\mathrm{Cj}-\mathrm{Zj}$. Kelebihan dari metode ini adalah mampu 
menghitung dua atau lebih variabel keputusan apabila dibandingkan dengan metode grafik yang hanya mampu mengaplikasikan dua variabel keputusan (Wijaya, 2013).

PT. Tass Engineering merupakan perusahaan yang bergerak di bidang industri karoseri truk. Kegiatan utamanya adalah memproduksi berbagai macam karoseri truk berbagai ukuran dan jenis. Saat ini untuk memenuhi permintaan pelanggan PT. Tass Engineering bekerja sama dengan pihak kedua (pemborong) untuk menyelesaikan permintaan pelanggan tersebut. Terdapat 4 tim pemborong untuk membuat 4 jenis produk PT. Tass Engineering, produkproduk tersebut ialah Dump Truck, Subframe, Tilting, dan Tanki Truck. Berikut pada tabel 1.1 data produksi dan total cost April 2018 - Maret 2019.

Tabel 1.1 Data Produksi dan Total Cost April 2018 - Maret 2019.

\begin{tabular}{|c|c|c|c|c|c|c|c|c|c|c|}
\hline \multirow{2}{*}{ TIM } & \multicolumn{2}{|c|}{ Dumpt Truck } & \multicolumn{2}{|c|}{ Subframe } & \multicolumn{2}{|r|}{ Tilting } & \multicolumn{2}{|c|}{ Tangki Truck } & \multirow{2}{*}{$\begin{array}{c}\text { Total } \\
\text { Produksi Unit }\end{array}$} & \multirow{2}{*}{ Total Cost } \\
\hline & Qty & Biaya & Qty & Biaya & Qty & Biaya & Qty & Biaya & & \\
\hline 1 & 15 & 18.000 .000 & 42 & 32.760 .000 & 1 & 2.120 .000 & 15 & 36.000 .000 & 73 & 88.880 .000 \\
\hline 2 & 19 & 26.600 .000 & 21 & 16.800 .000 & 12 & 24.000 .000 & 6 & 17.250 .000 & 58 & 84.650 .000 \\
\hline 3 & 22 & 27.830 .000 & 13 & 10.725 .000 & 3 & 5.700 .000 & 12 & 37.200 .000 & 50 & 81.455 .000 \\
\hline 4 & 16 & 21.200 .000 & 47 & 42.300 .000 & 5 & 10.575 .000 & 6 & 18.060 .000 & 74 & 92.135 .000 \\
\hline Total & & & & & & & & & & 347.120 .000 \\
\hline
\end{tabular}

Sumber : PT.TASS Engineering (2019)

Dari tabel di atas terlihat bahwa terjadi variasi jumlah pekerjaan yang dilakukan oleh tiap tim. Alokasi pekerjaan diberikan kepada tim yang sudah menyelesaikan pekerjaan tanpa melihat waktu dan biaya yang ditimbulkan. Berikut pada gambar 1 lebih jelasnya ditunjukkan biaya tiap tim untuk tiap produk :

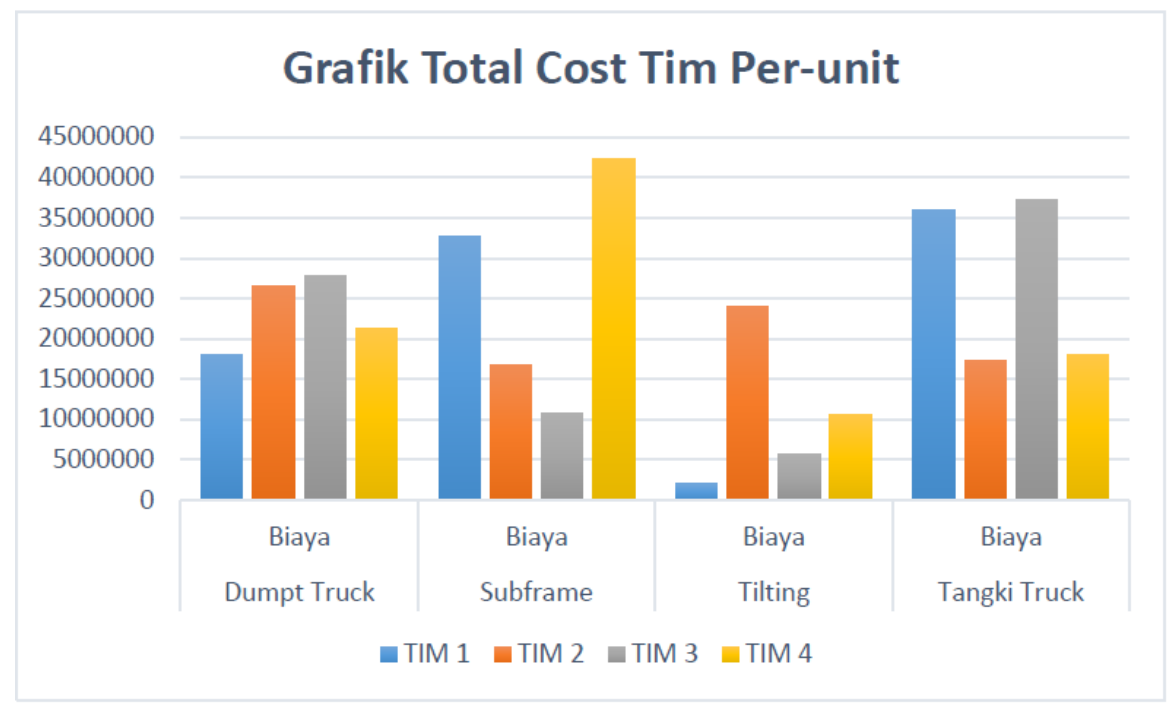

Gambar 1.1 Grafik Total Produksi dan Total Cost

Sumber: PT. TASS Engineering (2019)

Dari gambar 1.1 dan tabel 1.1 di atas terlihat bahwa dalam mengerjakan 1 produk setiap tim memberikan variasi biaya. Seperti pada produk Dump Truck biaya tertinggi adalah Rp. 27.830.000 dan biaya terendah Rp. 18.000.000. Selisihnya sebesar Rp. 9.830.000 atau 35,3\%. Pada produk Subframe biaya tertinggi adalah Rp. 42.300 .000 dan biaya terendah $\mathrm{Rp}$. 
10.725.000. Selisihnya sebesar Rp. 31.575 .000 atau 74,6\%. Pada produk Tilting biaya tertinggi adalah Rp. 24.000.000 dan biaya terendah Rp. 5.700.000. selisihnya sebesar Rp. 18.300.000 atau 76,25 \%. Pada produk Tanki Truck biaya tertinggi adalah Rp. 37.200.000 dan biaya terendah Rp. 17.250.000. Selisihnya sebesar Rp. 19.950 .000 atau 53,6\%.

Berdasarkan situasi di atas, terjadi perbedaan jumlah biaya yang harus dikeluarkan oleh perusahaan untuk tiap tim dengan produk yang sama. Dari situasi di atas pula pihak perusahaan ingin mengetahui tim mana yang paling optimal untuk memproduksi produk agar dapat menekan biaya kegiatan produksi. Hasil alokasi ini merupakan parameter untuk menentukan jumlah produksi masing-masing produk untuk mendapatkan keuntungan maksimum.

\section{METODOLOGI}

Tahapan penelitian adalah sebagai berikut :

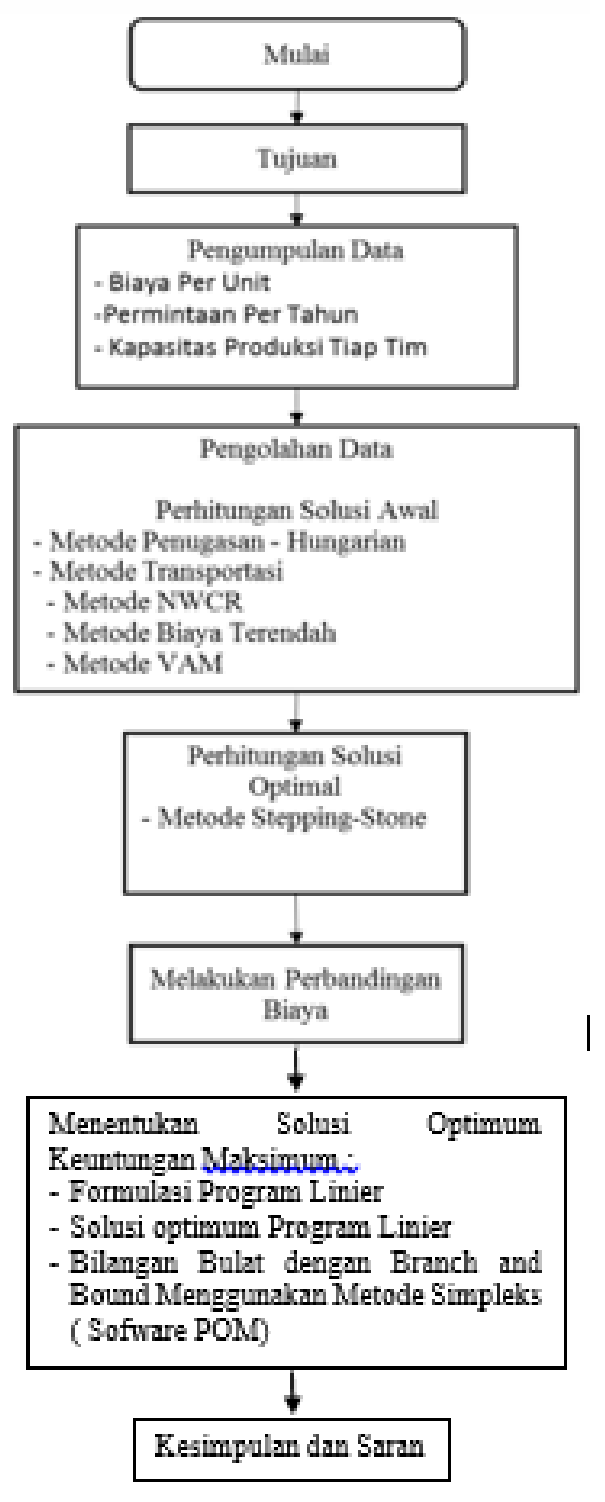

Gambar 2.1. Tahapan Penelitian Sumber : Pengolahan Data (2019) 
Pengolahan data akan dilakukan menggunakan perhitungan Metode Hungarian dan Metode Transportasi, tetapi sebelumnya harus mendapatkan data yang berhubungan dengan penelitian, yaitu :

A. Data yang dibutuhkan:

1. Data total produksi selama 3 tahun terakhir.

2. Waktu Produksi Tim tiap unit.

3. Kapasitas produksi tim/tahun.

4. Biaya tim per unit.

B. Perhitungan solusi awal dengan menggunakan :

1. Penugasan dengan menggunakan Metode Hungarian dengan cara memilih nilai terkecil tiap baris dan kolom lalu dilakukan pengurangan dari setiap baris dan kolom tersebut dengan nilai terkecil yang dipilih, kemudian tarik garis dengan melewati angka nol.

2. Metode Transportasi

- Metode Sudut Barat Laut (North West Corner Rules-NWCR), pengisian sel dimulai dari sel/kotak ujung kiri atas dengan jumlah alokasi maksimum, kemudian bergerak ke kotak kanan bila suplai cukup, atau bergerak kebawah untuk memenuhi permintaannya.

- Metode Biaya Terendah (Least Cost), pilih sel dengan biaya terkecil, alokasikan dengan jumlah maksimum, sesuaikan kembali hingga semua permintaan tercukupi.

- Metode Vogel Approximation (VAM), pilih baris atau kolom dengan nilai pinalti terbesar. Alokasikan dengan jumlah maksimum pada baris atau kolom yang dipilih. Sesuaikan kembali hingga semua permintaan tercukupi.

C. Hasil dari solusi awal selanjutnya dicari solusi optimal menggunakan :

- Metode Stepping-Stone, sel yang kosong ditentukan lintasan loopnya dan dihitung biayanya. Alokasikan sebanyak mungkin ke sel kosong yang memiliki nilai negatif terbesar untuk menghasilkan penurunan biaya.

D. Pemilihan solusi optimum antara penugasan Hungarian dan metode Transportasi

E. Hasil pilihan dijadikan parameter untuk memformulasikan Program Linier.

F. Tentukan solusi optimum yang memberikan keuntungan maksimum dengan Program Linier Bilangan Bulat dengan Branch and Bound melalui Metode Simpleks. Perhitungan dilakukan dengan software POM

\section{HASIL DAN PEMBAHASAN}

\subsection{Pengumpulan Data}

Berikut data-data yang dikumpulkan yaitu :

Tabel 3.1 Total Produksi PT. TASS Engineering 2016-2019

\begin{tabular}{|c|c|c|c|c|}
\hline \multicolumn{5}{|c|}{ Total Produksi PT. TASS Engineering } \\
\hline Tahun & $\begin{array}{c}\text { Dumpt } \\
\text { Truck }\end{array}$ & Subframe & Tilting & $\begin{array}{c}\text { Tanki } \\
\text { Truck }\end{array}$ \\
\hline $\begin{array}{c}\text { April 2016 - } \\
\text { Maret 2017 }\end{array}$ & 80 & 123 & 30 & 28 \\
\hline $\begin{array}{c}\text { April 2017 - } \\
\text { Maret 2018 }\end{array}$ & 66 & 119 & 32 & 30 \\
\hline $\begin{array}{c}\text { April 2018 - } \\
\text { Maret 2019 }\end{array}$ & 72 & 123 & 21 & 39 \\
\hline Total & 218 & 365 & 83 & 97 \\
\hline $\begin{array}{c}\text { rata-rata } \\
\text { demand }\end{array}$ & $\begin{array}{c}73 \\
\text { unit/thn }\end{array}$ & $\begin{array}{c}122 \\
\text { unit/thn }\end{array}$ & $\begin{array}{c}28 \\
\text { unit/thn }\end{array}$ & $\begin{array}{c}32 \\
\text { unit/thn }\end{array}$ \\
\hline
\end{tabular}


Sumber : PT. TASS Engineering (2019)

Dari tabel data di atas, dapat diketahui rata-rata permintaan dari tiap jenis produk untuk 1 tahun. Permintaan tersebut berupa 73 unit/tahun untuk produk dump truck, 122 unit/tahun untuk produk subframe, 28 unit/tahun untuk produk tilting, dan 32 unit/tahun untuk produk tanki truck.

Tabel 3.2 Waktu Produksi Tim untuk Tiap Unit di PT. TASS Engineering

\begin{tabular}{|c|l|l|l|l|}
\hline \multicolumn{6}{|l|}{ Waktu Produksi (hari) } & Subframe & Tilting & Tanki Truck \\
\hline Tim & Dump Truck & 1 & 6 & 7 \\
\hline 1 & 1 & 1 & 3 & 6 \\
\hline 2 & 2 & 1 & 7 & 6 \\
\hline 3 & 2 & 1 & 4 & 9 \\
\hline 4 & 3 & & \\
\hline
\end{tabular}

Sumber: PT. TASS Engineering (2019)

Tabel 3.2 menunjukkan jumlah waktu (hari) yang di perlukan setiap tim dalam menyelesaikan 1 produk dengan total jumlah hari kerja selama 1 tahun sebanyak 240 hari kerja. Untuk mendapatkan kapasitas produksi tiap tim, maka dilakukan perhitungan total hari kerja dibagi rata-rata pengerjaan produksi tiap tim.

Tabel 3.3 Kapasitas produksi tim/tahun di PT. TASS Engineering

\begin{tabular}{|c|c|}
\hline Tim & Kapasitas Produksi/tahun (unit) \\
\hline 1 & 64 \\
\hline 2 & 80 \\
\hline 3 & 60 \\
\hline 4 & 56 \\
\hline
\end{tabular}

Sumber: Pengolahan Data (2018)

Tabel 3.4 Data Produksi \& Total Biaya April 2018 - Maret 2019

\begin{tabular}{|c|c|c|c|c|c|c|c|c|c|c|}
\hline \multirow{2}{*}{ TIM } & \multicolumn{2}{|c|}{ Dumpt Truck } & \multicolumn{2}{|r|}{ Subframe } & \multicolumn{2}{|r|}{ Tilting } & \multicolumn{2}{|c|}{ Tangki Truck } & \multirow{2}{*}{\begin{tabular}{c|} 
Total \\
Produksi Unit \\
\end{tabular}} & \multirow{2}{*}{ Total Cost } \\
\hline & Qty & Biaya & Qty & Biaya & Qty & Biaya & Qty & Biaya & & \\
\hline 1 & 15 & 18.000 .000 & 42 & 32.760 .000 & 1 & 2.120 .000 & 15 & 36.000 .000 & 73 & 88.880 .000 \\
\hline 2 & 19 & 26.600 .000 & 21 & 16.800 .000 & 12 & 24.000 .000 & 6 & 17.250 .000 & 58 & 84.650 .000 \\
\hline 3 & 22 & 27.830 .000 & 13 & 10.725 .000 & 3 & 5.700 .000 & 12 & 37.200 .000 & 50 & 81.455 .000 \\
\hline 4 & 162 & 21.200 .000 & 47 & 42.300 .000 & 5 & 10.575 .000 & 6 & 18.060 .000 & 74 & 92.135 .000 \\
\hline & & & & & & & & & & 541.120 .000 \\
\hline
\end{tabular}

Sumber : PT. TASS Engineering (2019)

Biaya yang dicantumkan adalah biaya setiap tim dalam memproduksi setiap jenis produk. Biaya tersebut dapat dilihat pad tabel 3.4 berikut : 
Tabel 3.5 Biaya Tim Per Unit

\begin{tabular}{|c|c|c|c|c|}
\hline \multirow{2}{*}{ Pekerjaan } & \multirow{2}{*}{ Dump Truck } & Subframe & Tilting & Tanki Truck \\
\cline { 1 - 4 } Tim & 1.200 .000 & 780.000 & 2.120 .000 & 3.000 .000 \\
\hline 1 & 1.400 .000 & 800.000 & 2.000 .000 & 2.875 .000 \\
\hline 2 & 1.265 .000 & 825.000 & 1.900 .000 & 3.100 .000 \\
\hline 3 & 1.325 .000 & 900.000 & 2.115 .000 & 3.010 .000 \\
\hline
\end{tabular}

Sumber : Pengolahan Data (2019)

\subsection{Penugasan Hungarian}

Hasil perhitungan penugasan Hungarian adalah sebagai berikut :

Tabel 3.6 Alokasi Pekerjaan Menggunakan Metode Penugasan Hungarian

\begin{tabular}{|c|c|c|c|c|}
\hline \multirow{2}{*}{ Tim } & Produk & $\begin{array}{c}\text { Alokasi } \\
\text { Pekerjaan (unit) }\end{array}$ & $\begin{array}{c}\text { Biaya/Unit } \\
\text { (Rp) }\end{array}$ & Total Biaya (Rp) \\
\hline 1 & Dump Truck & 73 & 1.200 .000 & 87.600 .000 \\
\hline 2 & Subframe & 122 & 800.000 & 97.600 .000 \\
\hline 3 & Tilting & 28 & 1.900 .000 & 53.200 .000 \\
\hline 4 & Tanki Truck & 32 & 2.010 .000 & 64.320 .000 \\
\hline Total & \multicolumn{2}{r}{-} & & \\
\hline
\end{tabular}

Sumber : Pengolahan Data (2019)

Solusi di atas menyatakan tanki truck dikerjakan tim-4 sebanyak 32 unit. Waktu yang diperlukan tim-4 untuk memproduksi tiap unit tanki truck adalha 9 hari. Waktu yang diperlukan untuk memproduksi 32 unitn adalah sebesar 32 x $9=288$ hari per tahun, sementara jumlah hari yang tersedia adalah 240 hari. Dengan demikian Metode Penugasan Hungarian ini tidak dapat digunakan sebagai solusi.

\subsection{Metode Transportasi}

Berikut tabel awal untuk Metode Transportasi yang diperoleh dari tabel 3.1, tabel 3.3, tabel 3.5. 
Tabel 3.7 Tabel Awal Metode Transportasi

\begin{tabular}{|c|c|c|c|c|c|}
\hline produk & \multirow{2}{*}{$\begin{array}{c}\text { dump truck } \\
\text { (DT) }\end{array}$} & \multirow{2}{*}{$\begin{array}{c}\text { subframe } \\
\text { (SF) }\end{array}$} & \multirow{2}{*}{ tilting (TL) } & \multirow{2}{*}{$\begin{array}{c}\text { tangki truck } \\
\text { (TT) }\end{array}$} & \multirow{2}{*}{ capacity } \\
\hline tim & & & & & \\
\hline 1 & 1.200 & 780 & 2.120 & 3.000 & 64 \\
\hline 2 & 1.400 & 800 & 2.000 & 2.875 & 80 \\
\hline 3 & 1.265 & 825 & 1.900 & 3.100 & 60 \\
\hline 4 & 1.325 & 900 & 2.115 & 3.010 & 56 \\
\hline demand & 73 & 122 & 28 & 32 & \\
\hline
\end{tabular}

Sumber: PT. TASS Engineering (2017)

Solusi layak dasar dengan Metode Sudut Barat Laut (North West Corner Rules / NWCR) adalah:

Tabel 3.8 Alokasi Pekerjaan Menurut Metode Sudut Barat Laut (North West Corner Rules/NWCR )

\begin{tabular}{|c|c|c|c|c|}
\hline & Produk & $\begin{array}{c}\text { Alokasi } \\
\text { Pekerjaan } \\
\text { Tim }\end{array}$ & $\begin{array}{c}\text { Biaya per } \\
\text { unit (Rp) }\end{array}$ & $\begin{array}{c}\text { Jumlah Biaya } \\
\text { (Rp) }\end{array}$ \\
\hline 1 & Dumpt truck & 64 & 1.200 .000 & 76.800 .000 \\
\hline 2 & Dumpt truck & 9 & 1.400 .000 & 12.600 .000 \\
\hline 2 & Subframe & 71 & 800.000 & 56.800 .000 \\
\hline 3 & Subframe & 51 & 825.000 & 42.075 .000 \\
\hline 3 & Tilting & 9 & 1.900 .000 & 17.100 .000 \\
\hline 4 & Tilting & 18 & 2.115 .000 & 38.070 .000 \\
\hline 4 & tanki truck & 32 & 3.010 .000 & 96.320 .000 \\
\hline Total Biaya & \multicolumn{3}{|l}{} & 339.765 .000 \\
\hline
\end{tabular}

Sumber : Pengolahan Data ( 2019)

Solusi layak dasar dengan Metode Biaya Terendah (Least Cost) adalah : 
Tabel 3.9 Matriks Solusi Awal Metode Biaya Terendah (Least Cost)

\begin{tabular}{|c|c|c|c|c|}
\hline & Produk & $\begin{array}{c}\text { Alokasi } \\
\text { Pekerjaan } \\
\text { (Unit) }\end{array}$ & $\begin{array}{c}\text { Biaya per } \\
\text { unit (Rp) }\end{array}$ & $\begin{array}{c}\text { Jumlah Biaya } \\
\text { (Rp) }\end{array}$ \\
\hline 1 & Subframe & 64 & 780.000 & 49.920 .000 \\
\hline 2 & Subframe & 58 & 800.000 & 46.400 .000 \\
\hline 2 & Tilting & 17 & 2.000 .000 & 34.000 .000 \\
\hline 3 & Dumpt truck & 60 & 1.265 .000 & 75.900 .000 \\
\hline 4 & Dumpt truck & 13 & 1.325 .000 & 17.225 .000 \\
\hline 4 & Tilting & 11 & 2.115 .000 & 23.265 .000 \\
\hline 4 & Tanki truck & 32 & 3.010 .000 & 96.320 .000 \\
\hline Total Biaya & \multicolumn{3}{|l}{} & 343.030 .000 \\
\hline
\end{tabular}

Sumber : Pengolahan Data ( 2019)

Solusi layak dasar dengan Metode Metode Vogel Approximation ( VAM ) :

Tabel 3.10 Matriks Solusi Awal Metode Vogel Approximation ( VAM

\begin{tabular}{|c|c|c|c|c|}
\hline Tim & Produk & $\begin{array}{c}\text { Alokasi } \\
\text { Pekerjaan (Unit) }\end{array}$ & $\begin{array}{c}\text { Biaya per unit } \\
(\mathrm{Rp})\end{array}$ & $\begin{array}{c}\text { Jumlah Biaya } \\
(\mathrm{Rp})\end{array}$ \\
\hline 1 & Dump truck & 4 & 1.200 .000 & 4.800 .000 \\
\hline 1 & Tilting & 28 & 2.120 .000 & 59.360 .000 \\
\hline 1 & Tanki truck & 32 & 3.000 .000 & 96.000 .000 \\
\hline 2 & Subframe & 80 & 800.000 & 64.000 .000 \\
\hline 3 & Dump truck & 18 & 1.265 .000 & 22.770 .000 \\
\hline 3 & Subframe & 42 & 825.000 & 34.650 .000 \\
\hline 4 & Dump truck & 51 & 1.325 .000 & 67.575 .000 \\
\hline Total & \multicolumn{3}{|l}{} & 349.155 .000 \\
\hline
\end{tabular}

Sumber : Pengolahan Data ( 2019 ) 
Pengujian solusi optimal menggunakan Metode Batu Loncatan ( Stepping - stone) menggunakan solusi awal Metode sudut barat laut ( north west corner rules / NWCR ), Metode biaya terendah (least cost), dan Metode vogel approximation (VAM). Pengujiannya memberikan hasil yang sama. Perbedaan hanya pada banyaknya iterasi. Hasil optimum dengan menggunakan Metode Batu Loncatan ( Stepping - stone ) adalah :

Tabel 3.12 Matriks Transportasi Metode Stepping-Stone

\begin{tabular}{|c|c|c|c|c|c|c|}
\hline produk & \multirow{2}{*}{$\begin{array}{c}\text { dump truck } \\
\text { (DT) }\end{array}$} & \multirow{2}{*}{$\begin{array}{c}\text { subframe } \\
\text { (SF) }\end{array}$} & \multirow{2}{*}{ tilting (TL) } & \multirow{2}{*}{$\begin{array}{c}\text { tangki truck } \\
\text { (TT) }\end{array}$} & \multirow{2}{*}{ dummy } & \multirow{2}{*}{ capacity } \\
\hline tim & & & & & & \\
\hline \multirow{2}{*}{1} & 1.200 & 780 & 2.120 & 3.000 & 0 & \multirow{2}{*}{64} \\
\hline & 64 & $x$ & $x$ & $x$ & $x$ & \\
\hline \multirow{2}{*}{2} & 1.400 & 800 & 2.000 & 2.875 & 0 & \multirow{2}{*}{80} \\
\hline & $x$ & 48 & $x$ & 32 & $x$ & \\
\hline \multirow{2}{*}{3} & 1.265 & 825 & 1.900 & 3.100 & 0 & \multirow{2}{*}{60} \\
\hline & $x$ & 32 & 28 & $x$ & $x$ & \\
\hline \multirow{2}{*}{4} & 1.325 & 900 & 2.115 & 3.010 & 0 & \multirow{2}{*}{56} \\
\hline & 9 & 42 & $x$ & $x$ & 5 & \\
\hline demand & 73 & 122 & 28 & 32 & 5 & 260 \\
\hline
\end{tabular}

Tabel 3.12 Matriks Solusi Optimum dengan Metode Stepping-Stone

\begin{tabular}{|c|c|c|c|c|}
\hline \multirow{2}{*}{ Tim } & Produk & Pekerjaan (unit) & $\begin{array}{c}\text { Alokasi } \\
(\mathrm{Rp})\end{array}$ & $\begin{array}{c}\text { Biaya per unit } \\
(\mathrm{Rp})\end{array}$ \\
\hline 1 & Dumpt truck & 64 & Rp. 1.200.000 & 76.800 .000 \\
\hline 2 & Subframe & 48 & Rp. 800.000 & 38.400 .000 \\
\hline 2 & Tanki truck & 32 & Rp. 2.875.000 & 92.000 .000 \\
\hline 3 & subframe & 32 & Rp. 825.000 & 26.400 .000 \\
\hline 3 & Tilting & 28 & Rp. 1.900.000 & 53.200 .000 \\
\hline 4 & Dumpt truck & 9 & Rp. 1.325.000 & 11.925 .000 \\
\hline 4 & Subframe & 42 & Rp. 900.000 & 37.800 .000 \\
\hline Total Biaya & \multicolumn{3}{|l}{} & 336.525 .000 \\
\hline
\end{tabular}

Sumber : Pengolahan Data ( 2019) 
Alokasi pekerjaan yang optimal menurut MetodeSstepping - Stone adalah dump truck diproduksi tim-1 sebanyak 64 (0.88 bagian) dan tim-4 sebanyak 9 (0.12 bagian). Subframe diproduksi tim-2 sebanyak 48 (0.39 bagian), tim-3 sebanyak 32 ( 0.26 bagian) dan tim-4 sebanyak 42 ( 0.35 bagian). Tilting seluruhnya diproduksi sebanyak 28 oleh tim-3. Tanki truck seluruhnya diproduksi sebanyak 32 oleh tim-2.Biaya transportasi menurut Metode Stepping Stone sebesar Rp 336.525.000.

\subsection{Program Linier Bilangan Bulat (Integer Linier Programming)}

Keuntungan tiap unit dump truck adalah Rp 9.500.000, subframe adalah 5.000.000, tiltimg sebesar 10.000.000, dan tanki truck sebesar 20.000.000.

Waktu yang tersedia untuk tiap tim dalam setahun adalah 240 hari. Waktu yang dibutuhkan untuk produksi tiap produk untu tiap tim dapat dilihat pada tabel 3.2. Kendala "waktu tim" dibenntuk dari jumlah dan jenis apa yang diproduksi berdasarkan solusi optimum metode transportasi dan waktu pengerjaan tiap unit dari tiap tim.

Contoh :

Waktu tim-4 = (proporsi produksi dump truck oleh tim-4) $\mathrm{x}$ (waktu pengerjan dump truck oleh tim-4) + (proporsi produksi subframe oleh tim-4) x (waktu pengerjaan subframe oleh tim-4)

$=(0.12) \times(3) \mathrm{X}_{1}+(0.35) \times(1) \mathrm{X}_{2}=0.36 \mathrm{X}_{1}+0.35 \mathrm{X}_{2}$ tidak boleh lebih dari 240 hari. Demikian seterusnya untuk penentuan kendala "waktu tim" untk tim yang lainnya.

Formulasi Program Linier :

Maksimum $Z=9.500 .00 X_{1}+5.000 .000 X_{2}+10.000 .000 X_{3}+20.000 .000 X_{4}$ Dengan kendala:

\begin{tabular}{|c|c|c|c|c|c|}
\hline Kapasitas tim- $1=$ & $=0.88 \mathrm{X} 1$ & & & & $\leq 64$ \\
\hline Kapasitas tim-2 = & & $0.39 \mathrm{X}_{2}$ & + & $X_{4}$ & $\leq 80$ \\
\hline Kapasitas tim-3 = & & $0.26 \mathrm{X}_{2}+$ & $\mathrm{X}_{3}$ & & $\leq 60$ \\
\hline Kapasitas tim-4 = & $=0.12 \mathrm{X}_{1}+$ & $0.35 \mathrm{X}_{2}$ & & & $\leq 51$ \\
\hline Waktu tim-1 & $=0.88 \times 1$ & & & & $\leq 240$ \\
\hline Waktu tim-2 = & & $0.39 \mathrm{X}_{2}$ & + & $6 \mathrm{X}_{4}$ & $\leq 240$ \\
\hline Waktu tim-3 = & & $0.26 \mathrm{X}_{2}+$ & $7 X_{3}$ & & $\leq 240$ \\
\hline Waktu tim-4 = & $0.36 \mathrm{X}_{1}+$ & $0.35 \mathrm{X}_{2}$ & & $\mathrm{X}_{1}, \mathrm{X}_{2}$ & $\begin{array}{c}\leq 240 \\
X_{3}, X_{4} \geq 0\end{array}$ \\
\hline
\end{tabular}

integer

Dengan menggunakan POM Windows maka diperoleh solusi optimum seperti berikut :

$X_{1}=72,73$ unit, $X_{2}=120.77$ unit, $X_{3}=28.59$ unit, $X_{4}=32.14$ unit. Hasil solusi optimum ini menunjukkan nilai yang belum bulat, Untuk itu dilakukan pembulatan dengan Program Linier Bilangan Bulat dan diperoleh hasil yaitu $X_{1}=73$ unit, $X_{2}=120$ unit, $X_{3}=29$ unit, $X_{4}=33$ unit. Hasil ini memberikan keuntungan sebesar Rp 2. 243.500. Hasil ini juga merupakan target produksi yang merupakan target penjualan. Kondisi sekarang memberikan keuntungan rata-rata $\mathrm{Rp} 2.223 .500 .000$. Artinya dengan perhitungan biaya alokasi pekerjaan yang minimum maka diperoleh kenaikan keuntungan sebesar Rp 
20.000.000 atau sekitar 0.9\%. Jadi ditargetkan produksi :

Dump truck $=73$ unit dimana 64 unit dikerjaan tim-2 dan 9 unit oleh tim-2

Subframe $=120$ unit dimana 47 unit dikerjakan tim-2, 31 unit oleh tim-3, dan 42 unit oleh tim-4

Tilting = 29 uni yang seluruhnya dikerjakan tim-3

Tanki truck $=33$ unit yng seluruhnya dikerjakan tim-2

\section{KESIMPULAN}

Alokasi pekerjaan yang memberikan total biaya pengerjaan yang paling minimum memberikan dampak bagi keuntungan yang maksimum. Tim-1 mendapatkan 88\% pengerjaan dump truck, tim-2 mendapatkan pengerjaan subframe sebesar 39\% dan $100 \%$ tanki truck. Tim-3 mendapatkan pengerjaan subframe $26 \%$ dan $100 \%$ tilting. Tim-4 mendapatkan pengerjaan dump truck sebanyak $12 \%$ dan subframe sebanyak $35 \%$. Adapun target produksi yang merupakan target penjualan per tahun adalah dump truck 73 unit, subframe 120 unit, tlting 29 unit, dn tanki truck 33 unit. Target ini akan memberikan kenaikan keuntungan sebesar $0.9 \%$. Untuk penelitian selanjutya dapat melengkapi kendala dari Program Linier yaitu berupa material dan jumlah pekerja. Perhitungan kebutuhan atau permintaan dapat dilakukan dengan peramalan.

\section{DAFTAR PUSTAKA}

Azhar, K. Teori Pembuatan Keputusan. Jakarta: Lembaga Penerbit Fakultas Ekonomi Universitas Indonesia. 2013.

Gautama, I., Sarjono, H., \& Herman, R. Penerapan Metode Hungarian Pada Perusahaan Jasa. Binus Busines Review. 2013; 4(3);812-820.

Mulyono, S. Operational Research Edisi Kedua. Jakarta: Lembaga Penerbit Fakultas Ekonomi Universitas Indonesia.1999.

Paendong. M., \& Prang. J. Optimasi Pembagian Tugas Karyawan Menggunakan Metode Hungarian. Jurnal Ilmiah Sains. 2013; 11(1).

Rosta, J., \& Tannady, H. Pendistribusian Produk Yang Optimal Dengan Menggunakan Metode Transportasi. Jurnal Teknik dan Ilmu Komputer. 2012; 1(4)

Simbolon, L.D., Situmorang. M., \& Napitupulu. N. Aplikasi Metode Transportasi Dalam Optimasi Biaya Distribusi Beras Miskin (Raskin) Pada Perum Bulog Sub Divre Medan. Saintia Matematika. 2014;2(3),:299-311.

Siswanto, M. H., Sugiyanto, D., \& Nofendri, Y. (2017). PENGARUH LINE STOP TERHADAP LINE MENGGUNAKAN METODE KANBAN DI PT AKASHI WAHANA INDONESIA. Teknik dan Ilmu Komputer, 6(23).

Subagyo, Asri, \& Handoko. Dasar-dasar Operations Research Edisi Kedua. Yogyakarta: BPFE-Yogyakarta. 2013. 
Tarore. N., Walangitan, \& Sibi. M., Aplikasi Metode Stepping-Stone Untuk Optimasi Perencanaan Biaya Pada Suatu Proyek Konstruksi. Jurnal Sipil Statistik. 2015;1(8): 571-578. 